\title{
Prevalence of rheumatoid arthritis in families
}

\author{
A. G. WASMUTH ANd A. M. O. VEALE \\ From the Human Genetics Research Unit, New Zealand Medical Research Council, Medical School, University \\ of Otago, Dunedin, New Zealand \\ AND \\ D. G. PALMER AND T. C. HIGHTON \\ From the Rheumatic Diseases Unit, Wellcome Medical Research Institute, Department of Medicine, University \\ of Otago Medical School, Dunedin, New Zealand
}

Clinical experience over the years has led to the belief that there may be a significant familial aggregation of rheumatoid arthritis. Hangarter (1939), Edström (1941), Davidson (1952), Short (1952), Barter (1952), Stecher, Hersh, Solomon, and Wolpaw (1953), and Seppä (1957) all reported higher than expected prevalences of this disease amongst the relatives of probands with rheumatoid arthritis. Only the last two studies included controls. de Blécourt, Polman, and de Blécourt-Meindersma (1961), in a study of 7,000 relatives of probands, found that there was a higher prevalence of rheumatoid arthritis amongst the relatives than amongst the controls; but a short time later de Blécourt, Westendorp Boerma and Vorenkamp (1962), using the 1957 criteria of the American Rheumatism Association to define rheumatoid arthritis, found a much lower prevalence in the relatives than they might have expected from their previous study.

Masi and Shulman (1965) presented a well-documented review in which they criticized preceding reports which claimed to have demonstrated significant familial aggregation. Their main criticism was that these studies were inadequately or imperfectly controlled. The controls, although matched for race, age, and sex, were chosen without completely excluding environmental influences and socioeconomic variables. As most of the studies had been carried out within a particular practice or clinic, sampling was not representative, and in most cases the population from which the controls were selected had been underestimated.

Veenhof-Garmann, Steiner, Westendorp-Boerma, de Blécourt, and Valkenburg (1968) estimated the prevalence of rheumatoid arthritis in the spouses and first-degree relatives of a random sample of 105 patients with rheumatoid arthritis attending their clinic. They concluded that there was no increased incidence in the occurrence of rheumatoid arthritis and rheumatoid factor in either the relatives or in the spouses of patients with rheumatoid arthritis.

Likewise, Meyerowitz, Jacox, and Hess (1968), in a study and review of the evidence of rheumatoid arthritis in monozygotic sets of twins, came to the conclusion that discordance was far more common than concordance of rheumatoid arthritis in these pairs. This finding was evidence against the hypothesis that heredity was an important factor.

O'Brien, Bennett, Burch, and Bunim (1967) concluded their report on the prevalence of rheumatoid arthritis and rheumatoid factor in the Blackfeet and Pima Indians by stating that 'the data have shown no evidence that rheumatoid arthritis is distributed in any but a random fashion within the family'. Bennett and Burch (1968) later reported that 'Pima and Blackfeet Indians show familial aggregation of rheumatoid arthritis within a single generation'.

Rimôn (1969) investigated the relatives of 102 consecutive patients admitted to hospital for treatment of rheumatoid arthritis. He found 52 relatives with rheumatoid arthritis and concluded that this was a clear indication that rheumatoid arthritis had a strong familial prevalence. Hellgren (1969) reported a study of 157 husbands and 66 wives of patients with rheumatoid arthritis and concluded that the prevalence of rheumatoid arthritis amongst the spouses was no different from that amongst the general population.

While this paper was being prepared two important studies have appeared. Lawrence (1970), in his Heberden Oration, provided new twin data which had recently become available to him and reviewed previous studies. The concordance of seropositive disease in monozygous twins was found to be 33 times the expected rate and that in dizygous twins six times the expected rate. As the concordance rate in dizygous like-sexed twins was no greater than for other sibs, it was concluded that similarity of environment was not a factor in the incidence of concordance. Lawrence also emphasized the haphazard variation 
in the prevalence of clinical disease which occurred if the first and second New York criteria alone were used in establishing a diagnosis of rheumatoid disease. He concluded that a genetic predisposition is important for the development of seropositive rheumatoid arthritis and that further studies are still needed to identify the genes responsible and to assess the importance of environmental influences.

The second paper, by Lawrence, Valkenburg, Bremner, and Ball (1970), concerned the occurrence of rheumatoid factor in families. First-degree relatives showed higher titres for the sheep cell agglutination test and for the latex-fixation test for rheumatoid factor than did the local population, while spouses showed only the expected titres for their age. Familial aggregation seemed to depend on both tests being positive in the proband, the prevalence of rheumatoid arthritis being three times greater than expected in the relatives of the probands with dual positivity.

The purpose of the present study was to analyse the distribution of rheumatoid arthritis within families and, by being particularly careful in the choice of controls, to see if it were possible to demonstrate convincingly any familial aggregation of the disease.

\section{Methods}

From patients attending the Public Hospital Clinic for Rheumatic Diseases, Dunedin, New Zealand, and who were living in the city area, 201 were selected as probands. All fulfilled the New York criteria of Bennett and Wood (1968) and none warranted exclusion according to the C.I.O.M.S. list of exclusions. These probands were interviewed to determine whether or not any of their firstor second-degree relatives or any of the spouses of their first-and second-degree relatives suffered from a 'rheumatic complaint'. Similar information was also obtained for each proband's spouse. Information was collected for deceased as well as for living relatives and spouses. The numbers of relatives and spouses and their age, or age at death, were recorded. When a relative or spouse was said to have suffered from a 'rheumatic complaint', an attempt was made to obtain from any hospital or medical attendant such clinical information as would allow a diagnosis of rheumatoid arthritis to be made according to the four New York criteria (Bennett and Wood, 1968). In the case of a deceased relative, additional information was often obtained from the death certificate.

If it were not possible to determine whether or not a 'rheumatic' relative or spouse actually suffered from rheumatoid arthritis, the probability of his complaint being rheumatoid arthritis was estimated. This probability was calculated from the ratio of individuals said to have suffered from a 'rheumatic complaint' and confirmed as having suffered from rheumatoid arthritis to the total number of 'rheumatic' individuals for whom adequate clinical information was available.

Both relatives and spouses were regarded as having suffered from rheumatoid arthritis if two or more New York criteria were fulfilled. All deceased relatives and spouses who had rheumatoid arthritis recorded on their death certificates were arbitrarily regarded as having fulfilled two of the New York criteria. A complete description of the study method has been reported by Wasmuth (1969).

\section{Results}

\section{(A) PROBANDS}

The heterogeneity of the disease rheumatoid arthritis when classified by various recognized methods has been discussed by Wood (1968). An attempt was made to determine whether or not the cases of rheumatoid arthritis examined in this study were in fact homogeneous. Table I shows the age at onset of the female and male probands.

Table II sets out the distribution of female and male probands according to the particular New York criteria which were fulfilled in making the diagnosis of rheumatoid arthritis, together with the mean age of each group, the mean age at onset, and the mean duration of disease. There is no real difference between the various subclasses apart from the age at onset of the probands in relationship to the numbers of New York criteria which were fulfilled. The younger probands tended to fulfil fewer criteria and had a mean age which was closer to the mean age at onset of disease.

The total numbers of relatives and controls classified according to their relationship to the probands are set out in Table III. Family histories could not be obtained from two of the 201 probands. Information was obtained for over 90 per cent. of the probands' relatives but was less complete in the case of grandparents. All relatives or spouses who were living abroad were excluded arbitrarily. We have assumed that the exclusion of individuals who were abroad as well as those for whom no information was obtained was random in respect of those who may have suffered from rheumatoid arthritis. In most cases

Table I Probands classified by age at onset

\begin{tabular}{|c|c|c|c|c|c|c|c|}
\hline \multirow[t]{2}{*}{ Sex } & \multicolumn{7}{|c|}{ Age group (yrs) } \\
\hline & $15-24$ & $25-34$ & $35-44$ & $45-54$ & $55-64$ & $65-74$ & 75 \\
\hline $\begin{array}{l}\text { Female } \\
\text { Male }\end{array}$ & $\begin{array}{r}19 \\
6\end{array}$ & $\begin{array}{r}19 \\
3\end{array}$ & $\begin{array}{l}38 \\
11\end{array}$ & $\begin{array}{l}45 \\
13\end{array}$ & $\begin{array}{r}20 \\
5\end{array}$ & $\begin{array}{r}12 \\
3\end{array}$ & $\begin{array}{l}2 \\
2\end{array}$ \\
\hline
\end{tabular}


Table II Probands with rheumatoid arthritis, by number of positive N.Y. criteria (N.Y.C.)

\begin{tabular}{|c|c|c|c|c|c|c|}
\hline \multicolumn{2}{|l|}{ Sex } & \multirow{2}{*}{$\begin{array}{l}\begin{array}{l}\text { Classification } \\
(N . Y . C . \text { positive })\end{array} \\
1,2,3,4 \\
1,2,3 \text { only } \\
1 \text { and } 2 \text { only } \\
1 \text { only }\end{array}$} & \multirow{2}{*}{$\begin{array}{l}\text { No. } \\
93 \\
32 \\
20 \\
13\end{array}$} & \multirow{2}{*}{$\begin{array}{l}\text { Mean age }(y r s) \\
57 \cdot 4 \\
57 \cdot 5 \\
46 \cdot 4 \\
37 \cdot 4\end{array}$} & \multirow{2}{*}{$\begin{array}{l}\begin{array}{l}\text { Mean age at onset } \\
\text { (yrs) }\end{array} \\
44 \cdot 6 \\
45.7 \\
41 \cdot 5 \\
33.9\end{array}$} & \multirow{2}{*}{$\begin{array}{l}\text { Mean duration of } \\
\text { disease (yrs) } \\
12 \cdot 8 \\
11 \cdot 8 \\
5.4 \\
4 \cdot 5\end{array}$} \\
\hline Female & $\begin{array}{c}\text { I } \\
\text { II } \\
\text { III }\end{array}$ & & & & & \\
\hline Male & $\begin{array}{l}\text { I } \\
\text { II } \\
\text { III }\end{array}$ & $\begin{array}{l}1,2,3,4 \\
1,2,3 \text { only } \\
1 \text { and } 2 \text { only } \\
1 \text { only }\end{array}$ & $\begin{array}{r}22 \\
10 \\
9 \\
2\end{array}$ & $\begin{array}{l}57 \cdot 0 \\
59 \cdot 0 \\
46 \cdot 8 \\
59 \cdot 0\end{array}$ & $\begin{array}{l}46 \cdot 7 \\
50 \cdot 0 \\
39 \cdot 0 \\
54 \cdot 0\end{array}$ & $\begin{array}{r}10 \cdot 3 \\
9 \cdot 0 \\
7 \cdot 8 \\
4 \cdot 0\end{array}$ \\
\hline
\end{tabular}

Table III Numbers of relatives and spouses (controls) of probands with rheumatoid arthritis

\begin{tabular}{|c|c|c|c|c|c|}
\hline Relations & ip to proband & Number for whom & Number & Number for whom & Total number \\
\hline Relatives & $\begin{array}{l}\text { Sibs } \\
\text { Children } \\
\text { Parents } \\
\text { Grandparents } \\
\text { Uncles and aunts } \\
\text { Nephews and nieces }\end{array}$ & $\begin{array}{r}770 \\
288 \\
367 \\
401 \\
1,500 \\
1,289\end{array}$ & $\begin{array}{r}38 \\
4 \\
26 \\
201 \\
218 \dagger \\
38 \dagger\end{array}$ & $\begin{array}{c}4^{*} \\
\frac{9}{9} \\
72 \dagger \\
44 \dagger\end{array}$ & $\begin{array}{c}812 \\
292 \\
402 \\
804 \\
1,790 \dagger \\
1,371 \dagger\end{array}$ \\
\hline Controls & $\begin{array}{l}\text { Spouses of children } \\
\text { Spouses of uncles and aunts } \\
\text { Spouses of sibs } \\
\text { Spouses of nephews and nieces } \\
\text { Spouses of probands }\end{array}$ & $\begin{array}{r}155 \\
1,229 \\
634 \\
770 \\
165\end{array}$ & $\begin{array}{r}2 \\
158 \dagger \\
44 \dagger \\
41 \dagger \\
-\end{array}$ & $\begin{array}{c}-\overline{66 \dagger} \\
9 \dagger \\
68 \dagger \\
2\end{array}$ & $\begin{array}{c}157 \\
1,453 \dagger \\
687 \dagger \\
879 \dagger \\
167\end{array}$ \\
\hline
\end{tabular}

- Estimated numbers of sibs for one proband who was an adopted child

† Approximate number of relatives

it was possible to determine the actual number of relatives abroad or those for whom no information was provided. When this was not known an estimate was made of the number of relatives of that kind, from the mean number of relatives of each kind per proband.

(B) PROPORTION OF 'RHEUMATIC' RELATIVES AND CONTROLS FOUND TO HAVE RHEUMATOID ARTHRITIS

The actual proportions of relatives and spouses said to have suffered from rheumatic complaints who were found to have rheumatoid arthritis may be seen in Table IV. The probabilities of having rheumatoid arthritis were estimated for relatives said to have suffered a 'rheumatic complaint' but for whom no clinical information was available. These probabilities were 0.256 for first-degree relatives, 0.212 for second-degree relatives, and 0.152 for spouses. In the cases of deceased spouses and deceased relatives said to have suffered from a 'rheumatic complaint' with death certificates which made no mention of rheumatoid arthritis and for whom no other clinical information was available, the three probabilities have been reduced by the factor 0.637 . This factor was an estimate of the probability that a subject with rheumatoid arthritis might not have had this disease entered on his death certificate. This factor was

Table IV Analysis of relatives and their spouses (controls) said to have suffered from a 'rheumatic complaint (total numbers of relatives and controls for both male and female patients)

\begin{tabular}{|c|c|c|c|c|c|c|}
\hline \multirow[t]{2}{*}{ Series } & & \multirow{2}{*}{$\begin{array}{l}\text { Number said to have } \\
\text { had a rheumatic } \\
\text { complaint }\end{array}$} & \multicolumn{2}{|c|}{$\begin{array}{l}\text { Adequate clinical } \\
\text { information available }\end{array}$} & \multirow{2}{*}{$\begin{array}{l}\text { Number regarded } \\
\text { as having had } \\
\text { rheumatoid arthritis }\end{array}$} & \multirow{2}{*}{$\begin{array}{l}\text { Estimated probability } \\
\text { of having rheumatoid } \\
\text { arthritis } \dagger\end{array}$} \\
\hline & & & No. & Per cent. & & \\
\hline Relatives & $\begin{array}{l}\text { First-degree } \\
\text { Second-degree }\end{array}$ & $\begin{array}{l}208 \\
112\end{array}$ & $\begin{array}{r}156 \\
66\end{array}$ & $\begin{array}{l}75 \cdot 1 \\
58 \cdot 9\end{array}$ & $\begin{array}{l}40 \\
14\end{array}$ & $\begin{array}{l}0.2564 \pm 0.0350 \\
0.2121 \pm 0.0503\end{array}$ \\
\hline Controls & (all spouses) & 72 & 66 & $91 \cdot 8$ & 10 & $0.1515 \pm 0.0441$ \\
\hline
\end{tabular}

* Excludes those with only death certificate

number found to have rheumatoid arthritis

+ Probability of having suffered rheumatoid arthritis is the ratio: number for whom adequate clinical information was available 
determined from the finding that only eight of 22 patients with known rheumatoid arthritis (each positive for at least two New York criteria) had had rheumatoid arthritis recorded on their death certificates. The probability that rheumatoid arthritis would be mentioned on the death certificate of a subject who had in fact had this disorder was calculated to be 0.363 . The various methods used for confirming the diagnosis of rheumatoid arthritis for spouses and relatives are seen in Table V.

\section{Table V Confirmation of diagnosis}

Rheumatoid arthritis in relatives and controls Method of confirming diagnosis

No. of cases

Death certificates

Clinical examination at our clinic

Rheumatoid arthritis recorded in hospital notes, Dunedin Public Hospital

Diagnosed by general practitioners

Diagnosed by other hospitals

Response by general practitioners and hospitals to requests for clinical information for relatives and controls

\begin{tabular}{|c|c|c|c|}
\hline \multirow[t]{2}{*}{ Requests } & \multirow{2}{*}{$\begin{array}{l}\text { Number of } \\
\text { patients for whom } \\
\text { data was } \\
\text { requested }\end{array}$} & \multicolumn{2}{|c|}{ Response rate } \\
\hline & & No. & Per cent. \\
\hline $\begin{array}{l}\text { To general prac- } \\
\text { titioners } \\
\text { To hospitals }\end{array}$ & $\begin{array}{l}118 \\
39\end{array}$ & $\begin{array}{l}80 \\
33\end{array}$ & $\begin{array}{l}74 \cdot 5 \\
84 \cdot 3\end{array}$ \\
\hline
\end{tabular}

\section{PREVALENCE OF RHEUMATOID ARTHRITIS}

The prevalence of rheumatoid arthritis in both relatives and their controls may be seen in Table VI. Parents and grandparents have been excluded since they had no matched spouse controls. The prevalence of rheumatoid arthritis in the relatives of probands with grade 2 or more radiological changes (C.I.O.M.S. criteria, 1963) was also compared with that in their controls (spouses) and the difference was likewise highly significant $(P<0.001)$. When the prevalence in the relatives of those probands positive for any two New York criteria was compared with that in their controls (spouses) the difference was highly significant $(P<0.001)$. A different age structure was excluded as the cause of these differences. The mean age of all relatives and spouses (controls) was similar $(50.0$ and 54.5 yrs. respectively) with a similar distribution in the age groups.

PREVALENCE OF RHEUMATOID ARTHRITIS IN THE RELATIVES ACCORDING TO THE AGES OF THE PROBANDS AT THE ONSET OF THEIR DISEASE

Tables VII and VIII show that the prevalence of rheumatoid arthritis amongst first-degree relatives was the highest amongst the relatives of those probands who had developed their arthritis early in life. The prevalence of rheumatoid arthritis was less amongst the first-degree relatives of those probands who had developed their disease late in life. This pattern was less obvious when second-degree relatives were considered. The prevalence of rheumatoid arthritis was quite low in their case and the numbers in the samples were not large. The prevalence of rheumatoid arthritis in spouses of relatives according to the age at onset of the probands' arthritis similarly showed no clear pattern. The numbers in the samples were again small and the prevalence rate low. It should be noted that, in Tables VII, VIII, and IX, all relatives and spouses said to have suffered from a 'rheumatic complaint' but for whom no clinical information was available were included, using the calculated probabilities that their 'rheumatic complaint' was indeed rheumatoid arthritis.

PREVALENCE OF RHEUMATOID ARTHRITIS IN SPOUSES (CONTROLS)

The prevalence of rheumatoid arthritis amongst the

Table VI Prevalence of rheumatoid arthritis in relatives* and spouses of relatives $\dagger$ (controls) of rheumatoid arthritis probands

\begin{tabular}{|c|c|c|c|c|c|c|c|}
\hline \multirow[t]{3}{*}{ No. of persons } & \multicolumn{4}{|c|}{ Related to } & \multirow{2}{*}{\multicolumn{2}{|c|}{ All relatives pooled }} & \multirow{3}{*}{$\begin{array}{l}\text { Total } \\
\text { number of } \\
\text { persons }\end{array}$} \\
\hline & \multicolumn{2}{|c|}{ Male probands } & \multicolumn{2}{|c|}{ Female probands } & & & \\
\hline & $\begin{array}{l}\text { First- } \\
\text { degree }\end{array}$ & $\begin{array}{l}\text { Second- } \\
\text { degree }\end{array}$ & $\begin{array}{l}\text { First- } \\
\text { degree }\end{array}$ & $\begin{array}{l}\text { Second- } \\
\text { degree }\end{array}$ & No. & Per cent. & \\
\hline Relatives with rheumatoid arthritis & 8 & 7 & 19 & 8 & 42 & $1 \cdot 12$ & 3,751 \\
\hline $\begin{array}{l}\text { Spouses (controls) with rheumatoid } \\
\text { arthritis and positive for any two } \\
\text { N.Y.C. }\end{array}$ & & & & & 7 & $0 \cdot 26$ & 2,726 \\
\hline
\end{tabular}

- Relatives = sibs, children, uncles, aunts, nephews and nieces

$\dagger$ Spouses of relatives $=$ controls $=$ spouses of sibs, of children, of uncles, of aunts, of nephews and of nieces 
Table VII Prevalence (per cent.) of rheumatoid arthritis in all first-degree relatives*, by age at onset of probands' $\dagger$ disease

\begin{tabular}{|c|c|c|c|c|}
\hline \multirow{2}{*}{$\begin{array}{l}\text { Proband's age group } \\
\text { according to onset of their disease }\end{array}$} & \multicolumn{4}{|c|}{ Relatives' age group (yrs) } \\
\hline & $15-34$ & $35-54$ & $55-74$ & $75+$ \\
\hline $15-34$ & $\begin{array}{l}2 \cdot 82 \pm 1 \cdot 86 \\
(80)\end{array}$ & $\begin{array}{l}5 \cdot 37 \pm 2 \cdot 61 \\
(75)\end{array}$ & $\begin{array}{l}4 \cdot 34 \pm 2 \cdot 14 \\
(90)\end{array}$ & $\begin{array}{l}6 \cdot 17 \pm 5 \cdot 01 \\
(22)\end{array}$ \\
\hline $35-54$ & $\begin{array}{l}1 \cdot 17 \pm 0 \cdot 78 \\
(193)\end{array}$ & $\begin{array}{l}3 \cdot 41 \pm 1 \cdot 16 \\
(242)\end{array}$ & $\begin{array}{l}4 \cdot 20 \pm 1 \cdot 21 \\
(274)\end{array}$ & $\begin{array}{l}2 \cdot 46 \pm 1 \cdot 63 \\
(91)\end{array}$ \\
\hline $55-74$ & $\begin{array}{l}0 \cdot 0 \\
(36)\end{array}$ & $\begin{array}{l}3 \cdot 10 \pm 2 \cdot 02 \\
(73)\end{array}$ & $\begin{array}{l}4 \cdot 42 \pm 2 \cdot 05 \\
(100)\end{array}$ & $\begin{array}{l}3 \cdot 17 \pm 2 \cdot 57 \\
(54)\end{array}$ \\
\hline $75+$ & $\begin{array}{l}0 \cdot 0 \\
(6)\end{array}$ & $\begin{array}{l}0 \cdot 0 \\
(5)\end{array}$ & $\begin{array}{l}0 \cdot 0 \\
(18)\end{array}$ & $\begin{array}{l}0.0 \\
(17)\end{array}$ \\
\hline
\end{tabular}

- First-degree relatives = sibs, children and parents

+ All probands positive for any two New York Criteria

Figures in parentheses (sample size)

Table VIII Prevalence (per cent.) of rheumatoid arthritis in all second-degree relatives*, by age at onset of probands' $\dagger$ disease

\begin{tabular}{|c|c|c|c|c|}
\hline \multirow{2}{*}{$\begin{array}{l}\text { Proband's age group } \\
\text { according to onset of their } \\
\text { disease }\end{array}$} & \multicolumn{4}{|c|}{ Relatives' age group (yrs) } \\
\hline & $15-34$ & $35-54$ & $55-74$ & $75+$ \\
\hline $15-34$ & $\begin{array}{l}0 \cdot 0 \\
(169)\end{array}$ & $\begin{array}{l}0.85 \pm 0.85 \\
(117)\end{array}$ & $\begin{array}{l}0.68 \pm 0.52 \\
(250)\end{array}$ & $\begin{array}{l}1 \cdot 38 \pm 1 \cdot 0 \\
(134)\end{array}$ \\
\hline $35-54$ & $\begin{array}{l}0.0 \\
(605)\end{array}$ & $\begin{array}{l}0.95 \pm 0.61 \\
(236)\end{array}$ & $\begin{array}{l}1 \cdot 10 \pm 0 \cdot 48 \\
(474)\end{array}$ & $\begin{array}{l}1.99 \pm 0.68 \\
(415)\end{array}$ \\
\hline $55-74$ & $\begin{array}{l}0 \cdot 0 \\
(114)\end{array}$ & $\begin{array}{l}0.0 \\
(121)\end{array}$ & $\begin{array}{l}0.75 \pm 0.66 \\
(169)\end{array}$ & $\begin{array}{l}1.04 \pm 0.85 \\
(143)\end{array}$ \\
\hline $75+$ & $\begin{array}{l}0 \cdot 0 \\
(17)\end{array}$ & $\begin{array}{l}0.0 \\
(32)\end{array}$ & $\begin{array}{l}0 \cdot 53 \pm 1 \cdot 14 \\
(40)\end{array}$ & $\begin{array}{l}0 \cdot 0 \\
(24)\end{array}$ \\
\hline
\end{tabular}

* Second-degree relatives $=$ grandparents, uncles, aunts, nephews and nieces

+ Probands all positive for any two New York Criteria

Figures in parentheses (sample size)

spouses of probands and the spouses of relatives (when separated according to age and to the 'degree of relationship' of these spouses to the probands by marriage) are shown in Table IX. The greater prevalence of rheumatoid arthritis in the spouses of the probands may be considered to be an indication of the importance of environmental factors.

\section{Discussion}

In deciding to use a clinic-based sample of patients with rheumatoid arthritis, it was assumed that each patient was referred to the clinic as a result of his clinical condition and not because an increased prevalence of rheumatoid arthritis in the family increased the chance of referral. This assumption was

Table IX Prevalence (per cent.) of rheumatoid arthritis in spouses (controls)

\begin{tabular}{|c|c|c|c|c|}
\hline \multirow[t]{2}{*}{ Spouses } & \multicolumn{4}{|c|}{ Age group of spouses (yrs) } \\
\hline & $15-34$ & $35-54$ & $55-74$ & $75+$ \\
\hline Of probands & $\begin{array}{l}0 \cdot 0 \\
(21)\end{array}$ & $\begin{array}{l}1 \cdot 56 \pm 1 \cdot 55 \\
(64)\end{array}$ & $\begin{array}{l}2 \cdot 04 \pm 1 \cdot 76 \\
(64)\end{array}$ & $\begin{array}{l}2 \cdot 41 \pm 5 \cdot 42 \\
(8)\end{array}$ \\
\hline Of first-degree relatives & $\begin{array}{l}0 \cdot 0 \\
(129)\end{array}$ & $\begin{array}{l}0.66 \pm 0.42 \\
(303)\end{array}$ & $\begin{array}{l}0.43 \pm 0.38 \\
(302)\end{array}$ & $\begin{array}{l}0 \cdot 0 \\
(64)\end{array}$ \\
\hline Of second-degree relatives & $\begin{array}{l}0 \cdot 0 \\
(443)\end{array}$ & $\begin{array}{l}0.04 \pm 0.10 \\
(356)\end{array}$ & $\begin{array}{l}0.49 \pm 0.27 \\
(679)\end{array}$ & $\begin{array}{l}0 \cdot 24 \pm 0.23 \\
(461)\end{array}$ \\
\hline
\end{tabular}

Figures in parentheses (sample size) 
probably valid, since the New Zealand medical system provides specialist attention for patients at hospital at no personal expense and there is no private rheumatological practice in Dunedin city. It was also assumed that follow-up of relatives and spouses who had suffered from rheumatoid arthritis was complete. Each proband was asked if relatives had any 'rheumatic complaint' and not specifically rheumatoid arthritis, since McKusick (1959) and Coste (1968) have demonstrated that questionnaires boost the number of affected individuals. For these reasons it was assumed that all relatives with rheumatoid arthritis were recorded amongst those having other rheumatic complaints.

Reliance upon a diagnosis of rheumatoid arthritis in affected relatives and spouses by medical practitioners other than ourselves must have resulted in some diagnostic variability. Such variability ought, however, to have been uniform for both the relatives and their spouses (controls).

In the past comparisons of the prevalence of rheumatoid arthritis have been made between relatives of patients with rheumatoid arthritis and either the general population or the relatives of individuals selected as 'disease-free'. Environmental differences between the study group and the controls could be quite large under such circumstances. The present study differed in the selection of controls, in that comparisons were made between relatives of probands with rheumatoid arthritis on the one hand and their spouses on the other, in order that such differences be reduced to a minimum.

When the prevalence in the relatives of probands with rheumatoid arthritis was compared with that in their spouses, the relatives were found to have had a greater incidence of rheumatoid arthritis which was highly significant. This difference could have been the result of either genetic or environmental factors acting in the earlier years of life, or both. Probands who contracted rheumatoid arthritis early in life had the highest prevalence of rheumatoid arthritis in their first-degree relatives. This pattern was present but was less clear amongst the second-degree relatives.

Although the observed pattern of the prevalence of rheumatoid arthritis amongst the relatives of probands with early ages at disease onset strongly suggested a genetic factor for this group, the finding of an increased incidence amongst the older spouses suggested that environmental factors must have had some influence. The relative magnitudes of environmental and genetic factors require further study.

\section{Summary}

(1) A method for collecting information to determine if there is any significant familial aggregation of rheumatoid arthritis has been described.

(2) Comparisons of the prevalence of rheumatoid arthritis amongst relatives of patients with the disease and amongst the spouses of these relatives showed a much higher prevalence amongst the relatives $(P<0.001)$.

(3) When the probands were classified according to the age at onset of their disease, it was found that those patients who had developed their disease early in life had a higher prevalence of rheumatoid arthritis amongst their relatives than those who developed their arthritis later in life.

(4) The prevalence of rheumatoid arthritis amongst the spouses of the probands was found to be greater than the prevalence amongst the spouses of first- and second-degree relatives. This was thought to have been due to environmental effects $(P<0.001)$.

The authors are grateful to the Medical Research Council of New Zealand and the Otago Medical Research Foundation (Incorporated) for financial assistance, and to the practitioners who provided information.

\section{References}

BARTER, R. W. (1952) Ann. rheum. Dis., 11, 39 (Familial incidence of rheumatoid arthritis and acute rheumatism in 100 rheumatoid arthritics)

Bennett, P. H., AND BurCH, R. A. (1968) Arthr. and Rheum., 11, 546 (The distribution of rheumatoid factor and rheumatoid arthritis in the families of Blackfeet and Pima Indians)

- AND WoOD, P. H. N. (1968) 'Diagnostic criteria used in these surveys', in 'Population Studies of the Rheumatic Diseases, Proceedings of the Third International Symposium, New York, 1966', p. 477. Int. Congr. Ser., No. 148, Excerpta Medica Foundation, Amsterdam

Blécourt, J. J. De, Polman, A., ANd Blécourt-Meindersma, T. De (1961) Ann. rheum. Dis., 20, 215 (Hereditary factors in rheumatoid arthritis and ankylosing spondylitis)

—, Westendorp Boerma, F., AND VorenkAMP, E. O. (1962) Ibid., 21, 339 (Rheumatoid arthritis factor in near relatives of sero-positive and sero-negative patients with rheumatoid arthritis)

CosTE, F. (1968) 'Concerning the validity of genetic studies and population surveys in the rheumatic diseases', in 'Population Studies of the Rheumatic Diseases, Proceedings of the Third International Symposium, New York, 1966', ed. P. H. Bennett and P. H. N. Wood, p. 123. Excerpta Medica Foundation, Amsterdam

Council For INTERnational Organizations of Medical Sciences (1963) 'The Epidemiology of Chronic Rheumatism', vol. 2, 'Areas of Standard Radiographs of Arthritis,' pp. 24-32. Blackwell Scientific Publications, Oxford 
DAvidson, L. S. P. (1952) 'A controlled investigation into the aetiology of rheumatoid arthritis', in 'Rheumatic Diseases; based on the Proceedings of the VII International Congress' [prepared American Rheumatism Association], p. 1. Saunders, Philadelphia

EDström, G. (1941) Acta med. scand., 108, 398 (Klinlische Studien über den chronischen Gelenkrheumatismus; das Erbbild)

HANGARTER, W. (1939) 'Das Erbbild der rheumatischen und chronischen Gelenkerkrankungen'. Steinkopff, Dresden

HeLlgren, L. (1969) Acta rheum. scand., 15, 135 (Rheumatoid arthritis in both marital partners)

LAWRENCE, J. S. (1970) Ann. rheum. Dis., 29, 357 (Heberden Oration, 1969. Rheumatoid Arthritis-Nature or Nurture?)

- Valkenburg, H. A., Bremner, J. M., AND Ball, J. (1970) Ibid., 29, 269 (Rheumatoid factors in families)

McKusick, V. A. (1959) Amer. J. Med., 26, 283 (Genetic factors in diseases of connective tissues: A survey of the present state of knowledge)

Masi, A. T., AND Shulman, L. E. (1965) Arthr. and Rheum., 8, 418 (Familial aggregation and rheumatoid disease)

MeYerowitz, S., JACOX, R. F., AND Hess, D. W. (1968) Ibid., 11, 1 (Monozygotic twins discordant for rheumatoid arthritis: a genetic, clinical and psychological study of eight sets)

O’Brien, W. M., BennetT, P. H., Burch, T. A., AND Bunim, J. J. (1967) Ibid., 10, 163 (A genetic study of rheumatoid arthritis and rheumatoid factor in Blackfeet and Pima Indians)

Rimôn, R. (1969) Acta rheum. scand., Suppl. 13 (Social and psychosomatic aspects of rheumatoid arthritis)

SEPPÄ, U. (1957) Ibid., 3, 92 (A study on the hereditary disposition to rheumatoid arthritis)

SHORT, C. L. (1952) 'Factors associated with the onset of rheumatoid arthritis', in Proceedings of the VII International Congress' [American Rheumatism Association]. Saunders, Philadelphia

Stecher, R. M., Hersh, A. H., Solomon, W. M., and Wolpaw, R. (1953) Amer. J. hum. Genet., 5, 118 (The genetics of rheumatoid arthritis)

Veenhof-Garmann, A. M., Steiner, F. J. F., Westendorp-Boerma, F., Blécourt, J. J. de, and Valkenburg, H. A. (1968) 'The prevalence of rheumatoid arthritis and rheumatoid factor in relatives and spouses of seropositive and seronegative patients suffering from definite or classical rheumatoid arthritis', in 'Population Studies of the Rheumatic Diseases, Proceedings of the Third International Symposium, New York, 1966' ed. P. H. Bennett and P. H. N. Wood, p. 123. Excerpta Medica Foundation, Amsterdam

Wasmuth, A. G. (1969) 'A Study of the Biology and Genetics of the Disease Rheumatoid Arthritis'. M.Sc. thesis presented to the University of Otago, Dunedin, New Zealand

Wood, P. H. N. (1968) 'Age and the rheumatic diseases', in 'Population Studies of the Rheumatic Diseases, Proceedings of the Third International Symposium, New York, 1966', ed. P. H. Bennett and P. H. N. Wood, p. 26. Excerpta Medica Foundation, Amsterdam 